\title{
Assessing Argumentative Writing Skills in Online Environments among Arabic Language Teachers of Grades 5 to 7 in UAE Schools
}

\author{
https://doi.org/10.3991/ijet.v15i18.13581 \\ Suad Abdelkareem Alwaely ( $₫)$ \\ Al Ain University, Abu Dhabi, UAE \\ Hashemite University, Zarqa, Jordan \\ Suad.alwaelyeaau.ac.ae \\ Hanene Lahiani \\ Al Ain University, Abu Dhabi, UAE \\ University of Sfax, Sfax, Tunisia
}

\begin{abstract}
The study at hand aims at identifying the argumentative writing skills among Arabic language teachers in online environments. The need for acceptance and the readiness of teachers to work independently in a digital environment is now especially great since students are familiar with electronic technology. Peculiarities of teaching the Arabic language require increased attention to learning writing and confident knowledge from teachers. Argumentative writing is important for teachers precisely in terms of its use to motivate students in e-learning and increase their engagement. Research paper points to the relationship between teachers' writing skills and students' advancement in writing when learning Arabic, especially as a foreign language. To achieve the purpose of the study, the descriptive method was applied. The sample of the study consisted of 120 teachers of UAE primary schools (40 male and 80 female), who were chosen randomly. The instrument of the study is a questionnaire divided into seven areas of argumentative writing. The study evaluates writing skills closely related to the effectiveness of presenting information to an online audience and in preparing e-learning programs. The results show that the argumentative writing skills in Arabic language teachers are moderate. There are statistically significant differences on the argumentative writing skills attributed to the gender variable in favor of the females. There are no statistically significant differences among the sample participants ascribed to qualification variable. Finally, there are statistically significant differences on argumentative writing skills ascribed to the experience variable, in favor of 10 years of experience or more. The authors also offered recommendations for the application of research results and for further research in this area.
\end{abstract}

Keywords - Arabic language teachers; online environments; argumentative writing skills; persuasive writing. 


\section{Introduction}

The purpose of teaching how to write is to enable students to express themselves in writing, extend their perceptions, generate vocabulary, put it in order, and achieve its cohesion in order to control the correct language usage and the written expression rules, such as: statement correctness; organized and clear thinking; punctuation use; dividing the text into paragraphs [1].

Writing is a social process, and argumentation requires two or more participants to make an interaction and social communication. Human tends to argue to prove his/her point of view, express his/her opinion and justify his/her actions in daily life [2]. Hyland [3] believes that the writing process goes through multiple stages: planning, composing, reviewing, editing, and publishing. The first three processes: planning, composing, and reviewing, are the most often used processes in writing. They require the learner to be trained to perform those processes, develop his/her attitudes toward them, and develop his/her capacities to use them in all situations of formal and informal writing.

Argumentative writing requires students to possess definite points of view to convince the reader and make him/her adopt these points of view or adopt the same thinking perspective. This kind of writing requires the author to draw, design, prepare, and form his/her knowledge within argumentative frameworks, or within the argumentative context, using online tools [4]. Argumentative writing is also called persuasive writing, because it concentrates on readers' background information, preferences, attitudes and ideas. Argumentative writing is among basic and important skills that students should acquire at school; it helps evaluate their capacities and performance [5]. On the academic level, argumentative writing helps students to acquire knowledge. It enhances literary taste and scientific thinking skills, fosters the understanding of social and historical studies, increases motivation, problem-solving skills as well as online learning skills [6].

Argumentative writing can be regarded one of the ICT tools that concentrate on the readers, their preferences, and their information or attitudes. Its purpose is not only to inform the readers, but also to motivate them to change their opinions or attitudes and to make them take another stand, with good use of dialectics and logic [7]. In the context of online learning and the use of digital environment to increase effectiveness of a language learning process, writing skills are especially important $[4,8,9]$. Many indicate that writing skills in Arabic language are the most difficult and complex to acquire. These skills require at least basic higher order thinking skills [10]. The writing involves setting a goal, studying the composition of the text, oriented to the reader, the subsequent verification of the correctness of the presentation and communication of thoughts and grammatical correctness of the presentation [11,12]. Therefore, researchers in the teaching of the Arabic language suggest the use of language skills as the primary stage of teaching. It is especially important to use authentic materials, which make it possible to motivate students and help them overcome and reduce the anxiety associated with learning a complex foreign language [13,14].

The argumentative writing attracted some researchers to investigate its relationships or its effects on other variables. For example, Huang and Morgan [15] aimed to 
examine the effect of the functional method in understanding the cognitive context of science, especially conceptual maps and charts, by improving argumentative dialogue skills and illustrative expression. The results showed improvement in the scientific knowledge through the improvement of dialogue and writing skills. Johnson [16] also conducted a study to distinguish between public arguments, which concentrate on public concerns, and private arguments, which concentrate on issues between two individuals using the functional approach. The findings showed that public argument issues were functionally better in terms of acquiring and exposing information, and better in interpreting points of view than the individual argument issues. Abdulhaq and Alahmad [17] found that students' level of performance in the written argument was substandard, and there was a contrast between argumentative writing of $2 \mathrm{nd}$, 3rd, and 4th year students. Other researchers obtained similar results in relation to students and teachers, who interact with the digital environment of online learning $[10,18,19]$. Argumentative writing skills are especially important when there is no direct contact with the teacher. In addition, when students are not ready to express their thoughts reasonably, they mainly rely on oral speech than on writing skills. Alara'ra [20] found that there is a lack of argumentative writing skills among the students of "Arabic Language Teacher" major in Yarmouk University. However, there were no differences between males and females, and the students from the city outperformed the students from the countryside in argumentative writing skills.

Researchers of Arabic language and the methods of its teaching indicate that the Arabic language has an ancient pedagogical tradition. Unlike modernity, earlier emphasis was placed on the study of the written language, which determined interest in teaching methods on graphics, grammar and vocabulary. In this case, a secondary role was assigned to the study of the spoken language [9,21]. The main motivation in the study of the Arabic language has historically been the desire to join the sacred texts of the Koran, as well as to join the Arab culture and trade. In the modern world, this motivation, in fact, has slightly changed. Now, the most powerful incentive for learning the Arabic language is the study of religion, as well as its use for commercial purposes.

Important features of the modern Arabic language are its richness and significant difference in its dialects in different regions of the Arab world. Classical written language is the most important source of not only preservation of historical information, but also a means of intra-Arab communication between representatives of different dialects prevailing in certain countries [12,21]. Therefore, proficiency in literate classical writing is crucial not only for students of Arabic as a foreign language, but also for Arabic students.

The main purpose is to identify the availability of argumentative writing skills among Arabic language teachers from their own perspective. This study stems its importance from its subject. It is expected to add a new idea to the field of education sciences with regard to the availability of argumentative writing among the teachers. The study can also be relevant for researchers in education sciences that focus on using argumentative writing in Arabic language courses. The study is aimed at improving exactly those writing skills in Arabic that are most critical in the formation of Arabic language knowledge as a primary, second or a foreign language in terms of e- 
learning, multimedia and mobile technology or blended learning [22]. The study seeks to create an opportunity for the practitioners in schools and teaching facilities to review their approaches and improve their students' performance. It is hoped to help them know the strengths and weaknesses of writing practices.

\section{Methods}

\subsection{Research design and sample}

The descriptive methodology was used in the current study as the most appropriate to answer its questions. The participants were randomly taken from the study's population. The questionnaires $(n=180)$ were distributed (total population was 220). Only 120 questionnaires were returned. Therefore, there were 120 participants.

\subsection{Study instrument}

To achieve the objective of this study, the researchers designed a questionnaire to explore the argumentative writing skills among Arabic language male and female teachers of the 5-7 grades, from their perspective. The instrument was designed through reviewing the previous studies such as those of Alara'ra [20], Abdulhaq and Alahmad [17], and Alkandari [23], and deriving some items to fit the purposes of the study. The researchers constructed a questionnaire that consisted of seven main dimensions of argumentative writing with 28 behavioral indicators. The dimensions were Presentation and writing skills, Opinion refuting skill, Context selecting skill, Opinion building skill, Opinion defending skill, Convincing skill, and Opinion justifying skill.

\subsection{Validity and reliability}

The researchers verified the validity of the questionnaire by presenting it to a group of experts. Some items were verbally modified according to the experts' comments. The factor loads of all dimensions in the scale are over 0.40 . In order to verify the internal consistency, the coefficient was calculated on a pilot sample taken out of the study sample, which consisted of 30 male and female teachers. According to Cronbach's alpha formula, the values of the dimension were $0.86,0.88,0.91,0.88$, $0.86,0.89,0.92$, respectively, and the total Cronbach's alpha was 0.95.

\subsection{Statistical analysis}

To analyze the responses of the sample participants, the researchers used means, standard deviations, Cronbach's Alpha coefficient, percentages, frequencies, (T) test, one-way ANOVA, and Scheffe test for post hoc comparisons. 


\section{Results}

\subsection{Results related to the first question}

How Arabic language teachers of 5-7 grades (in UAE schools) perceive their argumentative writing skills?

Results show that means range between 3.33-3.63; the item "Presentation and writing skills" ranks first with the highest mean 3.63. Meanwhile, "Opinion justifying skill" ranks last with a 3.33 mean and the overall mean of the argumentative writing skills is 3.47 .

Means and standard deviations were calculated for each skill item separately, which were as follows. Then means and standard deviations for the items of "Opinion Building Skill" were evaluated. These five items are: students adopt their opinions about writing; the student is convinced with the opinion he adopted in writing; students use terms that indicate their personality while writing; Students make suggestions and figures related to the writing topic; students explain their points of view while writing. Research shows that means range between 3.32-3.61; and item 1 "Students express their opinions in writing" ranks first with a mean of 3.61. On the other hand, item 3 "Students explain their points of view in writing" ranks last with 3.32 mean, and the overall mean for "Opinion building skill" is 3.47. The standard deviation for all set was 0.938. All items were evaluated in "Average" level.

Also identified means and standard deviations for items related to Opinion Defending Skill. Five such skills were highlighted: students clarify the truth of opinions related to their opinion while writing; students clarify the strength and importance of the proposed opinion in writing; students use comprehension in defending the written opinion; students provide logical proofs in defending their opinion in writing; students use facts and information that support their opinion in writing. All the means range between 3.36-3.57; item 9 "Students justify their opinions in writing" ranks first with a 3.57 mean. Meanwhile, item 6 "Students use facts to support their opinion in writing" ranks last, with a mean of 3.36, and, the overall mean for "Opinion defending skill" is 3.47. The standard deviation for all set was 0.845 . All items were evaluated in "Average" level.

Five statements representing Opinion Justifying Skill are also considered:

- "I make the advantages and disadvantages clear in the written ideas and opinions"

- "I link the causes with results when justifying the opinion in the writing"

- "I adopt justified conclusions about the situation in writing"

- "I justify his "agree or disagree" for the proposed issue while writing"

- "Students connect the opinion and the information in an argumentative way while writing"

The means range between 3.11-3.42; item 14 "Students make the advantages and disadvantages clear in the written ideas and opinions" ranks first with a mean of 3.42. On the other hand, item 15 "Students connect the opinion and the information in an argumentative way in writing" ranks last with a 3.11 mean, and, the overall mean of 
opinion justifying skill is 3.33. The standard deviation for all set was 0.881 . All items were evaluated in "Average" level.

Table 1. Means and standard deviations for items related to "Opinion refuting skill", in a descending order.

\begin{tabular}{|c|c|l|c|c|c|}
\hline Rank & Number & \multicolumn{1}{|c|}{ Item } & Mean & $\begin{array}{l}\text { Standard } \\
\text { deviation }\end{array}$ & Level \\
\hline 1 & 16 & $\begin{array}{l}\text { Students use proofs and logical illustrations for the suggested } \\
\text { opinions in writing. }\end{array}$ & 3.72 & 1.280 & Average \\
\hline 2 & 17 & $\begin{array}{l}\text { Students confuse between their opinion and the opposite } \\
\text { opinion in writing. }\end{array}$ & 3.44 & 1.086 & Average \\
\hline 3 & 18 & $\begin{array}{l}\text { Students annul the arguments without supporting justifica- } \\
\text { tion in writing. }\end{array}$ & 3.44 & 1.062 & Average \\
\hline & & Overall opinion refuting skill. & 3.53 & 1.050 & Average \\
\hline
\end{tabular}

Table 1 shows that the means range between 3.44-3.72; item 16 "Students use proofs and logical illustrations for the suggested opinions in writing" ranks first with a mean of 3.72. Meanwhile item 18 "Students annul the arguments without supporting justification in writing" ranks last with a 3.44 mean and, overall mean for opinion refuting skill is 3.53. All items in Table 1 were evaluated in "Average" level.

The means range between 3.34-3.47, item 21 "Students provide variety of proofs and illustrations in writing to change others' thoughts" ranks first with a mean of 3.47. Meanwhile, item 20 "Students use various argumentative and dialogue methods in writing to convince others to support their opinion" ranks last with a mean of 3.34, and overall mean for convincing skill is 3.41. Items related to Context Selecting Skill were identified as: students seek accuracy in choosing information depending on scientific method in writing; students produce new ideas and concepts to attract others while writing; students depend on controversial ideas to attract others while writing. The means range between 3.39-3.60; item 23 "Students seek accuracy in choosing information depending on scientific method in writing" ranks first with a mean of 3.60. Meanwhile, item 22 "Students depend on controversial ideas in writing to interest the reader" ranks last with a 3.39 mean, and overall mean for context selecting skill is 3.48. The standard deviation for all set was 0.985 . All items were evaluated in "High" level.

Items were identified in the following sentences: students comply with writing rules in presenting the subject; students follow logical progression while presenting the ideas in writing; students use conjunctions like (and, if, but....); students use appropriate and effective rhetorical methods while writing.

The means range between 3.52-3.84; item 27 "Students comply with writing rules in presenting the subject" ranks first with a mean of 3.84. Meanwhile, item 28 "Students use appropriate and effective rhetorical methods in writing" ranks last with a 3.52 mean, and overall mean for presentation and writing skills is 3.63 . The standard deviation for all set was 0.985. All items were evaluated in "Average" level. 


\subsection{Results related to the second question}

Are there statistically significant differences in argumentative writing skills among Arabic language teachers of 5-7 grades (in UAE) ascribed to gender, qualification, and experience variables?

Means and standard deviations were obtained to find out the degree of argumentative writing skills among Arabic language teachers according to the variables: gender, qualification, and experience. The researchers used (T) test to find the statistical differences between the means for gender and qualification variables, and One-way ANOVA analysis for the experience variable, as shown in Table 2.

Table 2. Means, standard deviations, and (T) test for the effect of gender on the degree of argumentative writing skills among Arabic language teachers

\begin{tabular}{|c|c|c|c|c|c|c|c|}
\hline & Gender & Number & Mean & $\begin{array}{l}\text { Standard } \\
\text { Deviation }\end{array}$ & T value & $\begin{array}{c}\text { Freedom } \\
\text { Degrees }\end{array}$ & $\begin{array}{c}\text { Statistical } \\
\text { Significance }\end{array}$ \\
\hline \multirow{2}{*}{$\begin{array}{l}\text { Opinion building } \\
\text { skill }\end{array}$} & Male & 40 & 3.21 & 1.098 & -2.785 & 158 & 0.006 \\
\hline & Female & 80 & 3.63 & 0.789 & & & \\
\hline \multirow{2}{*}{$\begin{array}{l}\text { Opinion defending } \\
\text { skill }\end{array}$} & Male & 40 & 3.14 & 0.877 & -4.017 & 158 & 0.000 \\
\hline & Female & 80 & 3.67 & 0.761 & & & \\
\hline \multirow{2}{*}{$\begin{array}{l}\text { Opinion justifying } \\
\text { skill }\end{array}$} & Male & 40 & 3.12 & 0.985 & -2.327 & 158 & 0.021 \\
\hline & Female & 80 & 3.45 & 0.790 & & & \\
\hline \multirow{2}{*}{$\begin{array}{l}\text { Opinions refuting } \\
\text { skill }\end{array}$} & Male & 40 & 3.39 & 1.064 & -1.327 & 158 & 0.187 \\
\hline & Female & 80 & 3.62 & 1.037 & & & \\
\hline \multirow[t]{2}{*}{ Convincing Skill } & Male & 40 & 3.12 & 1.066 & -3.287 & 158 & 0.001 \\
\hline & Female & 80 & 3.60 & 0.761 & & & \\
\hline \multirow{2}{*}{$\begin{array}{l}\text { Context selecting } \\
\text { skill }\end{array}$} & Male & 40 & 3.21 & 1.143 & -2.648 & 158 & 0.009 \\
\hline & Female & 80 & 3.64 & 0.883 & & & \\
\hline \multirow{2}{*}{$\begin{array}{l}\text { Presentation and } \\
\text { writing skills }\end{array}$} & Male & 40 & 3.16 & 1.036 & -5.105 & 158 & 0.000 \\
\hline & Female & 80 & 3.92 & 0.834 & & & \\
\hline \multirow{2}{*}{$\begin{array}{l}\text { Overall } \\
\text { argumentative } \\
\text { writing skills } \\
\end{array}$} & Male & 40 & 3.18 & 0.865 & -3.878 & 158 & 0.000 \\
\hline & Female & 80 & 3.64 & 0.622 & & & \\
\hline
\end{tabular}

Table 2 shows statistically significant differences at $\alpha=0.05$ level, ascribed to the effect of gender in all areas, and in argumentative writing skills in general; except in the opinion refuting skill, where differences are in favor of females. 
Table 3. Means, standard deviations, and (T) test of the effect of qualification on the degree of argumentative writing skills among Arabic language teachers

\begin{tabular}{|c|c|c|c|c|c|c|c|}
\hline & Qualification & Number & Mean & $\begin{array}{l}\text { Standard } \\
\text { Deviation }\end{array}$ & T value & $\begin{array}{c}\text { Freedom } \\
\text { Degrees }\end{array}$ & $\begin{array}{c}\text { Statistical } \\
\text { Significance }\end{array}$ \\
\hline \multirow{2}{*}{$\begin{array}{l}\text { Opinion build- } \\
\text { ing skill }\end{array}$} & Bachelors & 72 & 3.49 & 0.975 & 0.495 & 158 & 0.622 \\
\hline & Post Graduate & 48 & 3.40 & 0.829 & & & \\
\hline \multirow{2}{*}{$\begin{array}{l}\text { Opinion de- } \\
\text { fending skill }\end{array}$} & Bachelors & 72 & 3.43 & 0.867 & -1.036 & 158 & 0.302 \\
\hline & Post Graduate & 48 & 3.59 & 0.773 & & & \\
\hline \multirow{2}{*}{$\begin{array}{l}\text { Opinion justify- } \\
\text { ing skill }\end{array}$} & Bachelors & 72 & 3.36 & 0.883 & 0.806 & 158 & 0.422 \\
\hline & Post Graduate & 48 & 3.23 & 0.879 & & & \\
\hline \multirow{2}{*}{$\begin{array}{l}\text { Opinion refut- } \\
\text { ing skill }\end{array}$} & Bachelors & 72 & 3.55 & 1.039 & 0.264 & 158 & 0.792 \\
\hline & Post Graduate & 48 & 3.50 & 1.091 & & & \\
\hline \multirow{2}{*}{$\begin{array}{l}\text { Convincing } \\
\text { skill }\end{array}$} & Bachelors & 72 & 3.40 & 0.961 & -0.263 & 158 & 0.793 \\
\hline & Post Graduate & 48 & 3.45 & 0.780 & & & \\
\hline \multirow{2}{*}{$\begin{array}{l}\text { Context select- } \\
\text { ing skill }\end{array}$} & Bachelors & 72 & 3.50 & 1.008 & 0.459 & 158 & 0.647 \\
\hline & Post Graduate & 48 & 3.41 & 1.019 & & & \\
\hline \multirow{2}{*}{$\begin{array}{l}\text { Presentation } \\
\text { and writing } \\
\text { skills }\end{array}$} & Bachelors & 72 & 3.71 & 0.976 & 1.840 & 158 & 0.068 \\
\hline & Post Graduate & 48 & 3.38 & 0.983 & & & \\
\hline \multirow{2}{*}{$\begin{array}{l}\text { Overall argu- } \\
\text { mentative } \\
\text { writing skills }\end{array}$} & Bachelors & 72 & 3.48 & 0.794 & 0.481 & 158 & 0.631 \\
\hline & Post Graduate & 48 & 3.42 & 0.637 & & & \\
\hline
\end{tabular}

Table 3 shows that there are no statistically significant differences at $\alpha=0.05$ level, imputed to qualification.

Table 4. Means and standard deviations for the availability of argumentative writing skills among Arabic language teachers according to teaching experience variable

\begin{tabular}{|l|l|c|c|c|}
\hline \multicolumn{1}{|c|}{ Skills } & \multicolumn{1}{|c|}{ Category } & Number & Mean & $\begin{array}{c}\text { Standard } \\
\text { Deviation }\end{array}$ \\
\hline \multirow{5}{*}{ Opinion building skill } & Less than 5 years & 18 & 3.06 & 1.157 \\
\cline { 2 - 5 } & From 5 to 10 years & 58 & 3.32 & 0.826 \\
\cline { 2 - 5 } & More than 10 years & 44 & 3.83 & 0.817 \\
\cline { 2 - 5 } & Total & 120 & 3.47 & 0.938 \\
\hline \multirow{5}{*}{ Opinion defending skill } & Less than 5 years & 18 & 2.78 & 0.847 \\
\hline & From 5 to 10 years & 58 & 3.41 & 0.873 \\
\cline { 2 - 5 } & More than 10 years & 44 & 3.86 & 0.535 \\
\hline & Total & 120 & 3.47 & 0.845 \\
\hline \multirow{5}{*}{ Opinion justifying skill } & Less than 5 years & 18 & 2.80 & 0.784 \\
\hline & From 5 to 10 years & 58 & 3.21 & 0.862 \\
\hline & More than 10 years & 44 & 3.70 & 0.789 \\
\hline & Total & 120 & 3.33 & 0.881 \\
\hline \multirow{5}{*}{ Opinion refuting skill } & Less than 5 years & 18 & 3.20 & 1.167 \\
\hline & From 5 to 10 years & 58 & 3.61 & 1.094 \\
\hline & More than 10 years & 44 & 3.61 & 0.918 \\
\hline & Total & 120 & 3.53 & 1.050 \\
\hline \multirow{5}{*}{ Convincing skill } & Less than 5 years & 18 & 2.77 & 0.910 \\
\hline & From 5 to 10 years & 58 & 3.47 & 0.998 \\
\hline
\end{tabular}


Paper-Assessing Argumentative Writing Skills in Online Environments among Arabic Language ..

\begin{tabular}{|l|l|c|c|c|}
\hline \multirow{4}{*}{ Context selecting skill } & More than 10 years & 44 & 3.67 & 0.651 \\
\cline { 2 - 5 } & Total & 120 & 3.41 & 0.916 \\
\hline \multirow{5}{*}{ Presentation and writing skills } & Less than 5 years & 18 & 3.04 & 1.078 \\
\cline { 2 - 5 } & From 5 to 10 years & 58 & 3.38 & 1.115 \\
\cline { 2 - 5 } & More than 10 years & 44 & 3.80 & 0.725 \\
\cline { 2 - 5 } & Total & 120 & 3.48 & 1.008 \\
\hline \multirow{5}{*}{$\begin{array}{l}\text { Argumentative writing skills in } \\
\text { general }\end{array}$} & Less than 5 years & 18 & 3.13 & 1.080 \\
\cline { 2 - 5 } & From 5 to 10 years & 58 & 3.63 & 1.059 \\
\cline { 2 - 5 } & More than 10 years & 44 & 3.87 & 0.752 \\
\cline { 2 - 5 } & Total & 120 & 3.63 & 0.985 \\
\hline & Less than 5 years & 18 & 2.96 & 0.890 \\
\cline { 2 - 5 } & From 5 to 10 years & 58 & 3.41 & 0.802 \\
\cline { 2 - 5 } & More than 10 years & 44 & 3.77 & 0.420 \\
\cline { 2 - 5 } & Total & 120 & 3.47 & 0.755 \\
\hline
\end{tabular}

Table 4 shows contrast in the means and standard deviations for the availability of argumentative writing skills among Arabic language teachers, ascribed to the differences in the teaching experience. To find statistically significant differences, the researchers used the One-way ANOVA analysis, as shown in Table 5.

Table 5. One-way ANOVA analysis for the effect of teaching experience on the argumentative writing skills among Arabic language teachers

\begin{tabular}{|c|c|c|c|c|c|c|}
\hline Skills & Source & Total squares & $\begin{array}{c}\text { Freedom } \\
\text { degrees }\end{array}$ & $\begin{array}{l}\text { Squares } \\
\text { Mean }\end{array}$ & F Value & $\begin{array}{c}\text { Statistical } \\
\text { Significance }\end{array}$ \\
\hline \multirow{3}{*}{$\begin{array}{l}\text { Opinion } \\
\text { building skill }\end{array}$} & Inter-Groups & 14.612 & 2 & 7.306 & 9.161 & 0.000 \\
\hline & Intra-Groups & 125.219 & 117 & 0.798 & & \\
\hline & Total & 139.831 & 119 & & & \\
\hline \multirow{3}{*}{$\begin{array}{l}\text { Opinion } \\
\text { defending skill }\end{array}$} & Inter-Groups & 24.005 & 2 & 12.003 & 21.072 & 0.000 \\
\hline & Intra-Groups & 89.426 & 117 & 0.570 & & \\
\hline & Total & 113.431 & 119 & & & \\
\hline \multirow{3}{*}{$\begin{array}{l}\text { Opinion } \\
\text { justifying skill }\end{array}$} & Inter-Groups & 17.815 & 2 & 8.907 & 13.242 & 0.000 \\
\hline & Intra-Groups & 105.605 & 117 & 0.673 & & \\
\hline & Total & 123.420 & 119 & & & \\
\hline \multirow{3}{*}{$\begin{array}{l}\text { Opinion } \\
\text { refuting skill }\end{array}$} & Inter-Groups & 4.103 & 2 & 2.052 & 1.883 & 0.156 \\
\hline & Intra-Groups & 171.052 & 117 & 1.090 & & \\
\hline & Total & 175.156 & 119 & & & \\
\hline \multirow{3}{*}{$\begin{array}{l}\text { Convincing } \\
\text { skill }\end{array}$} & Inter-Groups & 16.881 & 2 & 8.441 & 11.363 & 0.000 \\
\hline & Intra-Groups & 116.618 & 117 & 0.743 & & \\
\hline & Total & 133.499 & 119 & & & \\
\hline \multirow{3}{*}{$\begin{array}{l}\text { Context select- } \\
\text { ing skill }\end{array}$} & Inter-Groups & 12.584 & 2 & 6.292 & 6.625 & 0.002 \\
\hline & Intra-Groups & 149.109 & 117 & 0.950 & & \\
\hline & Total & 161.694 & 119 & & & \\
\hline \multirow{3}{*}{$\begin{array}{l}\text { Presentation } \\
\text { and writing } \\
\text { skills }\end{array}$} & Inter-Groups & 10.881 & 2 & 5.440 & 5.952 & 0.003 \\
\hline & Intra-Groups & 143.494 & 117 & 0.914 & & \\
\hline & Total & 154.375 & 119 & & & \\
\hline \multirow{3}{*}{$\begin{array}{l}\text { Overall argu- } \\
\text { mentative } \\
\text { writing skills }\end{array}$} & Inter-Groups & 13.860 & 2 & 6.930 & 14.161 & 0.000 \\
\hline & Intra-Groups & 76.829 & 117 & 0.489 & & \\
\hline & Total & 90.689 & 119 & & & \\
\hline
\end{tabular}


Table 5 shows statistically significant differences at $\alpha=0.05$ level ascribed to teaching experience in all areas and in argumentative writing skills in general, except the opinion refuting skill. The researchers used Scheffe test to find statistically significant differences among the means, as shown in Table 6.

Table 6. Scheffe Test (post-hoc test) for the effect of Teaching Experience on the argumentative writing skills among Arabic language teachers

\begin{tabular}{|c|c|c|c|c|c|}
\hline Skills & Experience & Mean & $\begin{array}{c}\text { Less than } 5 \\
\text { years }\end{array}$ & $\begin{array}{c}\text { From } 5 \text { to } 10 \\
\text { years }\end{array}$ & $\begin{array}{c}\text { More than } 10 \\
\text { years }\end{array}$ \\
\hline \multirow[t]{3}{*}{ Opinion building } & Less than 5 years & 3.06 & & & \\
\hline & From 5 to 10 years & 3.32 & 0.26 & & \\
\hline & More than 10 years & 3.83 & $0.77 *$ & $0.51 *$ & \\
\hline \multirow{3}{*}{ Opinion defending } & Less than 5 years & 2.78 & & & \\
\hline & From 5 to 10 years & 3.41 & $0.63 *$ & & \\
\hline & More than 10 years & 3.86 & $1.08 *$ & $0.45^{*}$ & \\
\hline \multirow{3}{*}{ Opinion justifying } & Less than 5 years & 2.80 & & & \\
\hline & From 5 to 10 years & 3.21 & 0.41 & & \\
\hline & More than 10 years & 3.70 & $0.90 *$ & $0.49 *$ & \\
\hline \multirow[t]{3}{*}{ Convincing } & Less than 5 years & 2.77 & & & \\
\hline & From 5 to 10 years & 3.47 & $0.70 *$ & & \\
\hline & More than 10 years & 3.67 & $0.91 *$ & 0.21 & \\
\hline \multirow[t]{3}{*}{ Context selecting } & Less than 5 years & 3.04 & & & \\
\hline & From 5 to 10 years & 3.38 & 0.33 & & \\
\hline & More than 10 years & 3.80 & $0.75 *$ & 0.42 & \\
\hline \multirow{3}{*}{$\begin{array}{l}\text { Presentation and } \\
\text { writing }\end{array}$} & Less than 5 years & 3.13 & & & \\
\hline & From 5 to 10 years & 3.63 & 0.49 & & \\
\hline & More than 10 years & 3.87 & $0.73 *$ & 0.24 & \\
\hline \multirow{3}{*}{$\begin{array}{l}\text { Overall argumen- } \\
\text { tative writing }\end{array}$} & Less than 5 years & 2.96 & & & \\
\hline & From 5 to 10 years & 3.41 & $0.46 *$ & & \\
\hline & More than 10 years & 3.77 & $0.82 *$ & $0.36^{*}$ & $0.36^{*}$ \\
\hline
\end{tabular}

* Significant at $\alpha=0.05$ level

Table 6 shows statistically significant differences at $\alpha=0.05$ level between teaching experience categories: "less than 5 years", "from 5 to 10 years" and "more than 10 years". The differences were in favor of teaching experience category "more than 10 years" in opinion building skill and opinion justifying skill. There were statistically significant differences at $\alpha=0.05$ level between teaching experience categories "less than 5 years" and "5-10 years", "more than 10 years". There were statistically significant differences at $\alpha=0.05$ level between experience category "from 5-10 years" and "more than 10 years" in favor of "more than 10 years" in opinion defending skill and argumentative writing skills in general. There were statistically significant differences at $\alpha=0.05$ level between teaching experience "less than 5 years" and "from 5-10 years", "more than 10 years", in favor of "5-10 years" and "more than 10 years" in convincing skill. Furthermore, there were statistically significant differences at $\alpha=0.05$ level between teaching experience "less than 5 years" and "more than 10 
years", in favor of "more than 10 years", in context selecting skill and presentation and writing skills.

\section{Discussion}

The results showed moderate argumentative writing skills among Arabic language male and female teachers. Means for all skills were very similar, however, writing and presentation skills ranked first, while opinion justifying skill was the last. The highest mean in writing and presentation skills could be ascribed to the following reasons. Continuous guidance of the teacher about the importance of complying with logical progression in writing, in its all types: argumentative, regular, functional or creative, about using conjunctions. Complying with writing rules, including the use of figures in the argumentative writing to be more convincing. This can be also ascribed to the teacher's role, who usually reviews different language dialects, which will reflect positively on practicing different writing skills, including the argumentative writing.

As for opinion justifying skill, which came in the last rank, it could be ascribed to the following fact. Justifying in general, and opinion justifying in particular, needs a writer with special skills, who has good cultural capacity, and has reviewed many different researches. Other reasons are related to teacher's lack of knowledge to oppose an idea, accept, or illustrate it, inability to connect the opinions, connect causes and results, especially the argumentative connection.

Opinion-justifying process needs a good capacity to enable and evoke the thoughts, which cannot be done without brainstorming process that leads to success in an argument. This is not common for most of Arabic language teachers who concentrate in their writing practice on proposing the ideas without argumentation.

Teachers whose skills were studied in the framework of this work could be actively involved in e-learning process. Teaching Arabic on the Web is becoming increasingly widespread and engaging an extremely wide international audience. In particular, mass online learning systems are being deployed in a number of Arab universities, and one of the most important disciplines they provide is Arabic [7,22,24,25]. The Arabian school, in particular, the higher one, actively uses modern teaching methods. In particular, the distribution of instructional content online has begun with Salman Khan. The latter, in 2004, posted records of his class activities on the Internet [13,26]. Given the peculiarities of the Arabic language and the emphasis on the primary development of speech skills, blended learning is widely spread. Namely, classes combine face-to-face activities with teacher and the use of multimedia content [19,22]. Considering the linguistic features of the Arabic language, in particular, dialect differences, researchers consider the use of authentic materials to be critical [2]. There are a significant number of studies focused on the use of documentaries and short films (up to 20 minutes) as the basis for mastering basic verbal skills [14,26,27]. This is especially important when using online learning. Writing skills in Arabic are closely related to authentic verbal material, therefore, many methods are proposed for written discussion of the seen video material, essay creation, collaborative processing of information, discussions on forums, etc. [27]. 
Recently, more and more attention has been paid to the fact that live speech is gradually turning into a special form - online communication in Arabic. At the same time, the means of online communication can be effectively used to teach actual living language using the example of live modern speech in close connection with written skills [28-30]. Written sub-skills are in the focus of attention of special education systems oriented both at school and at higher educational institutions. Such skills are developed on a modular basis; specific exercises and types of testing are aimed at each of the sub-skills. Therefore, it is especially important that teachers have appropriate sub-skills [26]. As for the argumentative writing sub-skills, the item "Students express their opinions in writing" scored first within "Opinion building skill". The researchers ascribe that to the Arabic language teacher's trust in the opinions proposed in the text by an author. As for "Opinion defending skill", the item "Students justify their opinions in writing" ranks first, because Arabic language teacher cares about conveying accurate information related to the author's point of view. Meanwhile, the item "Students use facts to support their opinion in writing" ranked last.

Regarding the "Opinion justifying skill", the item "Students make advantages and disadvantages clear in written ideas and opinions" ranked first, because the teacher wants to take his / her students away from negative issues while stating their opinions in writing. He / she wants them to justify their opinions and make them acceptable. Meanwhile, the item "Students connect the opinion and the information in an argumentative way in writing" ranked last. However, for "Opinion refuting skill", the item "Students use proofs and logical illustrations for the suggested opinions in writing", these proofs and logical illustrations will prevent contestation of the proposed subject. On the other hand, the item "Students annul the arguments without supporting justification in writing" ranked last.

As for the "Convincing skill", the item "Students provide variety of proofs and illustrations in writing to change others' thoughts" ranks first, because Arabic language teacher makes sure of guiding his/her students to be convincing about the written subject, and that variation of proofs and illustrations enriches the opinions and makes them acceptable. Meanwhile, the item "Students use various argumentative and dialogue methods in writing to convince others to support their opinion" ranked last. The researchers believe that Arabic language teacher is not concerned with search for different methods of argument and dialogue to convince the others, since he/she depends on proofs and illustrations in writing. Therefore, his/her opinion is effective and convincing to others.

Regarding the skill of selecting the context, the item "Students seek accuracy in choosing information depending on scientific method in writing" ranked first. Meanwhile, the item "Students depend on controversial ideas in writing to interest the reader" ranks last, because Arabic language teachers, by argumentative writing, do not try to bring in controversial matters, which lead to useless argument. Therefore, students try to focus on their own ideas. As for writing and presentation skills, the item "Students comply with writing rules in presenting the subject" ranked first. This could be ascribed to the Arabic language teachers' mastery in writing rules. Meanwhile, the item "Students use appropriate and effective rhetorical methods in writing" ranks last, because argument in writing does not need using metaphor, but the truth as a base. 
Regarding the agreement or disagreement between the previous studies and the current study, the researchers did not find studies that discussed the use of argumentative writing skills by teachers. There were studies related only to the availability of argumentative writing skills among the students. Some studies found a lack of these skills, in one hand. On the other hand, they were not discussed at all in other studies, such as Abdulhaq and Alahmad [17], and Alara'ra [20].

Findings show that there is an effect of the gender variable on the level of argumentative writing skills, in favor of the female teachers. The difference was in their favor in all areas of argumentative writing skills, except the area of "Opinion refuting", in which male and female teachers were equal. As for the evenness of male and female teachers in the degree of practicing opinion refuting skills, it might be a coincidence, or due to the close experience of male and female teachers in using proofs, illustrating the opposite opinion, and annulling proofs and evidences. There was no effect of the qualification variable on the argumentative writing skills practicing by Arabic language male and female teachers. There were statistically significant differences in argumentative writing skills ascribed to the experience variable in favor of more experienced ones.

\section{Conclusion}

The level of argumentative writing skills among Arabic language teachers, both men and women, was found to be moderate (according to the conducted testing in seven areas). First, the skills most closely related to the practice of teaching the Arabic language in the digital environment. Writing and presentation skills ranked the highest, and skills concerning opinion justification received the lowest marks. The highest score for writing and presentation skills can be explained by the continuous focus of teaching practices on the importance of following logical progress in writing in all its forms: argumentative, regular, functional or creative. The results showed that the gender variable affected the level of argumentative writing skills, which was in favor of women. Their skills prevailed in all the studied sub-skills, with the exception of "Opinion refutation" item, in which male and female teachers were equal. The reasons may be the superiority of women in the use of argumentative writing skills. This uniformity of male and female teachers may be a coincidence or because of close experience in using evidence. There was no influence of the qualification variable in determining the quality of skills of men and women. There were statistically significant differences in argumentative writing skills attributed to the experience variable in favor of more experienced ones.

In the light of the results, the following recommendations are suggested:

1. Organizing training workshops for Arabic language teachers to make them aware of argumentative writing skills.

2. Increasing the awareness of new teachers of argumentative writing skills and their role in developing students' writing abilities.

3. Conducting other studies about Arabic teachers' practice of argumentative writing in different school grades. 


\section{References}

[1] Alkadhi, B., Alsaif, S., Alangri, A., Alkallas, F., Aljadou, H., \& Altamimi, N. (2019). Labenah: An Arabic Block-Based Interactive Programming Environment for Children. The Journey of Learning and Playing. In International Conference on Human-Computer Interaction (pp. 179-187). Springer, Cham. https://doi.org/10.1007/978-3-030-23525-3_23

[2] Ali, F. F. I. (2008). The Argumentative Speech in Selections of American and Egyptian Media Texts. Unpublished Ph.D. Dissertation, Ain Shams University, Egypt.

[3] Hyland, K. (2003). Second language writing. Cambridge language education. Cambridge: Cambridge University Press.

[4] Zhang, X. (2018). Innovating Selection and Use of Online Writing Resources for EFL Students: A Systemic Functional Linguistic Perspective. International Journal of Emerging Technologies in Learning, 13(09), 136-147. https://doi.org/10.3991/ijet.v13i09.7910

[5] Abuhajjaj, A. (2010). The relationship between convincing writing skills development and deductive reading comprehension for some students of the secondary stage. Journal of Reading and Knowledge, 8, 1-5.

[6] Chinn, C. A. (2006). Learning to argue. In O'Donnell, A. M., Hmelo-Silver, C. E., \& Erkens, G. (Eds,), Collaborative learning, reasoning, and technology (pp. 355-383). Mahwah, NJ: Erlbaum. https://doi.org/10.4324/9780203826843

[7] Razak, N. A., Ab Jalil, H., \& Ismail, I. A. (2019). Challenges in ICT Integration among Malaysian Public Primary Education Teachers: The Roles of Leaders and Stakeholders. International Journal of Emerging Technologies in Learning, 14(24), 184-205. https://doi. org/10.3991/ijet.v14i24.12101

[8] Alwa, S. A. (2018). Argumentative Writing Skills among Arabic Language Teachers of the Seventh. Transylvanian Review, 1(1), 1-5.

[9] Mohammad, T., \& Hazarika, Z. (2016). Difficulties of learning EFL in KSA: Writing skills in context. International Journal of English Linguistics, 6(3), 105-117. https://doi. org/10.5539/ijel.v6n3p105

[10] Mahmudi, A. (2018). The Use of G-form as an Assessment Instrument in Arabic Language Teaching Based on HOTS. At-Tarbawi: Jurnal Kajian Kependidikan Islam, 3(2), 139-149. https://doi.org/10.22515/attarbawi.v3i2.1481

[11] Al-Jarrah, T. M., Mansor, N., Talafhah, R. H., Al-Jarrah, J. M., \& Al-Shorman, F. M. (2019). The Role of Metacognitive Technique for Enhancing the Writing Skills of Arab EEFL Students. Journal of Education in Black Sea Region, 4(2), 191-205. https://doi.org/ 10.31578/jebs.v4i2.179

[12] Rakhlin, N. V., Aljughaiman, A., \& Grigorenko, E. L. (2019). Assessing language development in Arabic: The Arabic language: Evaluation of function (ALEF). Applied Neuropsychology: Child, 1, 1-16. https://doi.org/10.1080/21622965.2019.1596113

[13] Jwaifell, M., Abu-Omar, R., \& Al-Tarawneh, M. (2018). The Readiness of Arabic Language Teachers for Integrating Flipped Classroom: Case of Ma'an. International Journal of Instruction, 11(4), 855-868. https://doi.org/10.12973/iji.2018.11454a

[14] Mat, A. C., Awang, A., Nokman, A. Z., Musilehat, N., \& Bakar, A. F. A. (2017). An authentic learning environment based on video project among Arabic learners. International Journal of Applied Linguistics and English Literature, 6(4), 143-148. https:// doi.org/10.7575/aiac.ijalel.v.6n.4p.143

[15] Huang, J., \& Morgan, G. (2003). A functional approach to evaluating content knowledge and language development in ESL students' science classification texts. International Journal of Applied Linguistics, 13(2), 234-262. https://doi.org/10.1111/1473-4192.00046 
[16] Johnson, A. J. (2009). A functional approach to interpersonal argument: Differences between public-issue and personal-issue arguments. Communication Reports, 22(1), 13-28. https://doi.org/10.1080/08934210902798528

[17] Abdulhaq H. \& Alahmad R. O. (2010). Methods of Teaching: Method, Manner, Medium. $1^{\text {st }}$ ed. Zarqa: Dar Almanahij for Publication and Distribution,

[18] Abdullah, M. A. O. A., \& Mohammed, M. M. K. (2018). The Effect of a Suggested Educational Software Based on Electronic Reading Activities in Teaching Grammatical Concepts on the development of Deductive Thinking Skills of First Year Secondary Students. International Journal of Innovation and Applied Studies, 22(2), 135-147.

[19] Kritz, M., Bachar, E., \& Shonfeld, M. (2018). An Online Collaborative Learning Model in a Multicultural Environment. In Shonfeld, M., \& Gibson, D. (Eds.), Collaborative learning in a global world (pp. 111-124). Charlotte: IAP.

[20] Alara'ra, W. M. (2010). The Level of Performance of Argumentative Writing by the Students of "Arabic Language Teacher" Major in Yarmouk University. Irbid, Jordan: Unpublished Thesis, Yarmouk University.

[21] Wahba, K. M. (2017). Language Learning and Teaching. In Wahba, K. M., England, L., Taha, Z. A. (Eds.), Handbook for Arabic language teaching professionals in the 21st century (Chapter 17). Routledge. https://doi.org/10.4324/9780203824757

[22] Hamdi, T., \& Abu Qudais, M. (2018). Optimising the blended learning environment: the Arab Open University experience. Open Learning: The Journal of Open, Distance and eLearning, 33(1), 46-62. https://doi.org/10.1080/02680513.2017.1414587

[23] Alkandari, A. (2010). Creative Expression Skills Development. $1^{\text {st }}$ ed. Kuwait: Kuwait Est. for Scientific Advancement.

[24] Daud, W. A. A. W., Ghani, M. T., \& Zaki, A. (2018). MOOC at Universiti Malaysia Kelantan: Need Analysis Study for the Development of Arabic Language Online Course. International Journal of Arts Humanities and Social Sciences, 1, 1-10.

[25] Omar, Z., \& Mukhtar, I. S. A. (2017). The Effect of Task-based Language Learning on Speaking and Writing Skills of Arabic Language Learners in International Islamic University Malaysia (IIUM). International Journal of Pedagogical Innovations, 5(02), 150-171. https://doi.org/10.12785/ijpi/050206

[26] Rahman, T. A. F. T. A., Chik, A. R., \& Sahrir, M. S. (2017). The Use of Documentary Film Text in Developing Arabic Writing Skills: What the Experts Say. LSP International Journal, 4(2), 59-71. https://doi.org/10.11113/1spi.v4n2.56

[27] Rahman, T. A. F. T. A., Chik, A. R., Sahrir, M. S., \& Nordin, M. S. (2017). A review of documentary film as authentic input in enhancing writing skills in ASL setting. Journal of Nusantara Studies, 2(1), 99-110. https://doi.org/10.24200/jonus.vol2iss1pp99-110

[28] Ahmad, W. R. W., \& Daud, N. M. (2011). Developing Arabic writing skills using Facebook. Retrieved July, 10, 2012. http://irep.iium.edu.my/4187/1/facebook_arabic _writing.pdf

[29] AlGhamdi, M. A. (2018). Arabic Learners' Preferences for Instagram English Lessons. English Language Teaching, 11(8), 103-110. https://doi.org/10.5539/elt.v11n8p103

[30] Altakhaineh, A. R. M., \& Al-Jallad, M. Z. (2018). The Use of Twitter and Facebook in Teaching Mechanics of Writing to Arabic-Speaking EFL Learners. International Journal of Emerging Technologies in Learning, 13(09), 4-14. https://doi.org/10.3991/ijet.v13i09. $\underline{8457}$ 


\section{$7 \quad$ Authors}

Suad Abdelkareem Alwaely works for Al Ain University in Abu Dhabi and for Hashemite University at Jordan. abdelkareemsuad@yahoo.com, Suad.alwaely@aau .ac.ae

Hanene Lahiani works in Al Ain University in UAE and also in University of Sfax at Sfax in Tunisia.

Article submitted 2020-02-05. Resubmitted 2020-06-01. Final acceptance 2020-06-09. Final version published as submitted by the authors. 